London (see also Nature, January 27, p. 158). Catlin was a self-taught artist and ethnographer. By contrast, Paul Kane (1810-71) was an artist by training and profession, and in his home in Toronto he had been familiar with the appearance and dress of Indians of various tribes who visited that seat of government. After travelling in the United States and studying in Europe, he set out on the first of his two expeditions among the Indians in 1845, when he spent five and a half months in recording portraits of "the principal chiefs, and their original costumes to illustrate their manners and customs, and to represent the scenery of an almost unknown country". In 1846 Kane started on his second and more important journey, which occupied two years and six months and extended across the continent to Fort Victoria. He did not keep a journal during his travels, and his book "Wanderings of an Artist among the Indians of North America" (1859) appears to have been written from memory.

Kane's sketches, exhibited on his return, attracted much interest, and a number of pictures were commissioned from him, some by the Government. Some of his pictures are now in the National Gallery, Ottawa, the House of Commons, Ottawa, and the Royal Ontario Museum of Archæology, Toronto. Of his field sketches, some are likewise preserved in Toronto, while a number are in the possession of David I. Bùshnell, jun. Reproductions of these have now been published with an account of the artist's life and work by the present owner (Smithsonian Miscell. Collect., 99, I ; 1940). They show a number of variations, important in an ethnographical sense, from the studio portraits and studies painted later.

\section{Tibetan Ceremonial and the Dalai Lama}

Since the revelation of the reincarnation of the late Dalai Lama in the body of a small boy and his entry into Lhasa, further observances of the ritual ceremonial have affirmed the youthful succession in his position-in this instance all the more necessary in view of the slight discrepancy between his age and the period of time that has elapsed since the death of his predecessor. Among these is the assumption of the new name or names by which the Dalai Lama will be known officially in future. These are, it is stated (The Times, February 9), Jampel Ngawang Lobsang Yishey Tenzing Gyatso, of which the meaning is "Tender Glory, Mighty in Speech, Excellent Intellect, Absolute Wisdom, Holding to the Doctrines, and Ocean-Wide". These names derive from titles of former Dalai Lamas, including the first, which was bestowed by the Mongol prince Yushi Khan.

Large numbers of Buddhist priests and nuns are now present in Lhasa for the installation ceremonies, and have attended the ceremonial performances which have taken place in the courtyard of the Potala, the vast monastic establishment in which the Dalai Lama resides. The important part of the New Year observance, as with many primitive peoples, and also among the more primitive of the
European peasantry even to-day, is the ceremonial of driving out all the evil influences of the Old Year. In Tibet this is of especial significance in view of the element of 'devil-worship' which has been introduced into the practices of Tibetan Buddhism, and the ecstatic 'devil-dances' in which its followers indulge more especially in eastern Tibet.

On this occasion, it is reported in a dispatch from Lhasa (The Times, February 12), the dancers, wearing masks representing the heads of stags or bulls and grinning skulls with fangs, enacted the reception for the skeleton dance which was performed by four skeleton dancers, with two attendant death's heads, scattering ashes. A magician wearing an apron of bones and a tall black hat topped with a fan-shaped ornament conjured spells from a skull while spinning in a rhythmic dance, which was the preliminary to ceremonies performed over an artificial corpse, which no doubt represented the Old Year, although this is not stated. Fire, as always a purificatory agent, appeared in the ceremonial when pictures of Tibetan devils were burned.

\section{Forgotten Methods of Painting}

IN his discourse on "Forgotten Methods of Painting" at the Royal Institution on February 2, Mr. Hesketh Hubbard spoke of the almost forgotten sfumato and botizar systems of oil painting, and dealt with the method of dusting dry powdered pigment over a sticky mordant which was used by some of the sixteenth and seventeenth century painters for laying certain pigments-a method known as 'strowing'. $\mathrm{He}$ outlined the technique of the fourteenth century English painters who worked in water-colour on woven linen; the linen was first saturated with gum. water, and then stretched over coarse woollen and frieze cloths which absorbed most of the colour, leaving the linen transparent after painting. The method of elydoric painting, or painting miniatures in oil whilst the painting ground was submerged in water, and the techniques of encaustic painting were among the topics mentioned.

In his ceaseless search for new pigments, before the chemist rendered him much assistance, the painter had not despised even the food upon his table. The great Paul Sandby himself had converted into pigment burnt crusts and peas that had been cooked to a cinder. Mr. Hubbard said that there is no reason to suppose that the painter has discovered all the manifold uses of his materials; the more media he has at his disposal the less restricted will be the mental outlook of the painter. Every medium of painting shares a frontier with one or more other media. At one point tempera touches fresco; at another it borders on oil painting. Glass painting and enamelling share much in common. It is along these frontiers, in the region of mixed methods, that the painter, in these latter days of painting will, in Mr. Hubbard's opinion, find the most profitable fields for experiment and research. For the same reason, the painter and student might profitably turn their attention, at least in their leisure hours, to some of the forgotten methods of painting. 